\title{
Detention of Undocumented Immigrants and the Judicial Impact of the CJEU's Decisions in France
}

\author{
ANA BEDUSCHI ${ }^{1}$
}

\begin{abstract}
In July 2012, the French Court of Cassation held that undocumented immigrants cannot be placed in police custody simply for being in the country illegally. The Court's judgments were preceded by a flurry of contradictory administrative measures and constitutional decisions. This confusion can be traced back to two landmark decisions handed down by the Court of Justice of the European Union in the cases of El Dridi and Achughbabian, which both dealt with the EU Returns Directive. It is argued here that prohibiting the placement of undocumented aliens in police custody is the result of a unique interplay between French criminal law and European Union law. This relationship between the two systems of law has been placed under strain by the French court's idiosyncratic interpretation of the CJEU's decisions. In its interpretation, the Court of Cassation has contributed to the transformation of detention from an extraordinary measure of last resort into an ordinary tool for combating illegal immigration. Based on this argument, this article draws conclusions on the French judicial authorities' balancing of individual rights and public interests in relation to aliens' rights.
\end{abstract}

\section{Introduction}

After more than fourteen months of judicial and administrative misunderstandings worthy of an Offenbach operetta, ${ }^{2}$ the First Civil Chamber of the French Court of Cassation stated that undocumented immigrants cannot be placed in police custody simply for being in the country illegally. ${ }^{3}$ The reaction of the French highest court ${ }^{4}$ follows the "earthquake" provoked by the Court of Justice of the European Union (CJEU) in 2011 when it handed down two important decisions concerning the Returns Directive ${ }^{6}$ in the cases of El Dridi ${ }^{7}$ and

\footnotetext{
${ }^{1}$ Dr Ana Beduschi, Lecturer in Law, University of Exeter School of Law. E-mail: a.beduschi@exeter.ac.uk. The author thanks Kubo Mačák and Richard Bowyer for their valuable insights and the Journal's anonymous reviewers for their instructive comments.

${ }^{2}$ The French judicial and administrative authorities adopted several diverging measures. First, by a circular of 12 May 2011, the former French Minister of Justice instructed all prosecutors to systematically appeal to the Court of Cassation on all decisions that favoured aliens. Second, the Criminal Chamber of the same court presented a legal opinion on the subject according to which the placement of undocumented migrants in police custody was illegal (Cass Crim., Advisory Opinion, 5 June 2012, n 9002, D 2012, 1997, obs. Ghislain Poissonnier). Third, the Constitutional Council held that there was no incompatibility between the statute and the Constitution, and that the placement of aliens in police custody was legal (C. C., $\mathrm{n}^{\circ}$ 2011-217QPC, Mohammed Alki B, 3 February 2012). Finally, the situation was clarified by the decisions of the First Civil Chamber of the Court of Cassation on 5 July 2012, which are discussed in this article.

${ }^{3}$ Cass. 1re civ., 5 July 2012, $\mathrm{n}^{\circ}$ 11.30-530: JurisData $\mathrm{n}^{\circ}$ 2012-014965; Cass. 1re civ., 5 July 2012, $\mathrm{n}^{\circ} 11-$ 30.371: JurisData ${ }^{\circ}$ 2012-014962; Cass. 1re civ., 5 July 2012, $\mathrm{n}^{\circ}$ 11-19.250: JurisData $\mathrm{n}^{\circ}$ 2012-014964.

${ }^{4}$ R Errera, 'France: Cour de Cassation finds detention of illegal aliens unlawful' [2012] PL 792.

${ }^{5}$ R Raffaelli, 'The Returns Directive in Light of the El Dridi Judgement' (2011) 3 Perspectives on Federalism 1. D Acosta Arcarazo and A Geddes, 'The Development, Application and Implications of an EU Rule of Law in the Area of Migration Policy' [2013] JCMS 179.

${ }^{6}$ Directive 2008/115/EC of 16 December 2008 on common standards and procedures in Member States for returning illegally staying third-country nationals [2008] OJ L348.

${ }^{7}$ Case C-61/11/PPU Hassen El Dridi, alias Soufi Karim [2011] ECR I-3015.
} 
Achugbabian. ${ }^{8}$ As a result of the interplay between French criminal law and European Union law, ${ }^{9}$ it is no longer permissible to place undocumented aliens in custody, despite this having long been accepted by the French public as a 'necessary evil'. ${ }^{10}$

As emphasised by Cathryn Costello, 'detention for committing a crime is conceptually and legally distinct from immigration detention'. ${ }^{11}$ However, insofar as irregular stay is considered a criminal offence punishable with up to one year's imprisonment, these two variants of detention can be conflated both in law and in practice. The former French system considered the irregular stay of aliens in French territory as a criminal offence punishable with a prison sentence. ${ }^{12}$ Thus, the provision laid down by the French code of criminal procedure allowing the arrest and placement of anyone suspected of committing a criminal offence punishable with imprisonment for at least one year in police custody for a maximum period of 48 hours $^{13}$ also applied to aliens staying in the country irregularly. Immigrants and unsuccessful asylum seekers suspected of staying irregularly in the French territory could thus be placed in police custody because irregular stay was considered a criminal offence.

In practice, the French police authorities had long been placing aliens in police custody to carry out inquiries about their situation and, where their stay was irregular, to keep them under surveillance until a detention order could be obtained. The police systematically made arrests with the aim of identifying immigrants sans papiers, who were then compelled to leave the country. ${ }^{14}$ After a period in police custody, these individuals were transferred to administrative detention centres where they awaited removal. ${ }^{15}$ Accordingly, police custody was used as a pre-detention or pre-removal tool by the public authorities. This practice can at best be described as the misapplication of a criminal procedure reserved by the French Criminal Code exclusively for cases concerning criminal offences punishable by imprisonment. ${ }^{16}$ This practice also led to the placement of individuals whose only supposed 'crime' was to have contravened French immigration laws in cells with potential 'true' criminals, suspected of murder, rape and robbery.

The French Court of Cassation ${ }^{17}$ noted this peculiar point of French criminal procedure and read it together with the decisions of the CJEU in the cases El Dridi ${ }^{18}$ and Achughbabian. ${ }^{19}$ According to these decisions, 'Directive 2008/115 precludes legislation

\footnotetext{
${ }^{8}$ Case C-329/11 A. Achughbabian v. Prefet du Val-de-Marne [2011] OJ C 32, 12.

${ }^{9}$ Directive 2008/115, above $n 6$.

${ }^{10} \mathrm{~J}$ Danet, 'La garde à vue et l'éloignement des étrangers en situation irrégulière : fin d'une époque' [2012] Revue de science criminelle 621.

${ }^{11} \mathrm{C}$ Costello, 'Human Rights and the Elusive Universal Subject: Immigration Detention under International Human Rights and EU Law’ (2012) 19 Indiana Journal of Global Legal Studies 257.

12 Article L621-1 French Code of Immigration and Asylum (repealed by the Law 2012-1560 of 31 December 2012, OJ 1 January 2013).

${ }^{13}$ Article 63 French Code of Criminal Procedure.

${ }^{14}$ A Bolis, 'Ce qui devrait changer avec la fin des gardes ‘a vue des sans papiers' Le Monde (Paris, 7 June 2012)<http://www.lemonde.fr/societe/article/2012/06/07/ce-que-changerait-la-fin-des-gardes-a-vue-desimmigres-sans-papiers_1714475_3224.html> accessed 23 May 2014. The charity CIMADE has identified that 74,000 people were placed in police custody in 2010: CIMADE, 'Migrations Etat des lieux 2012' $(2012)<$ http://cimade-production.s3.amazonaws.com/publications/documents/59/original/EDL-2012.pdf?1328258650> accessed 23 May 2014.

${ }^{15}$ CIMADE ibid 65.

${ }^{16}$ Article 63 French Code of Criminal Procedure.

${ }^{17}$ Cass. 1re civ., 5 July 2012, above n 3.

${ }^{18}$ Hassen El Dridi, above n 7.

${ }^{19}$ Achughbabian, above n 8, 12.
} 
from a Member State (...) which provides for a sentence of imprisonment to be imposed on an illegally staying third-country national on the sole ground that he remains, without valid grounds, on the territory of that State, contrary to an order to leave that territory within a given period' ${ }^{20}$ Drawing conclusions about this specific interplay between French criminal law and EU law, the French Court of Cassation rightly decided that aliens cannot be placed in police custody for the sole reason of being suspected of staying irregularly in French territory.

The reasoning of the Court was simple: if EU law precludes French legislation from imposing a prison sentence for the criminal offence of illegal stay, then the provision allowing the placement of individuals in police custody cannot apply to third-country nationals for the sole reason of illegal stay. In other words, as imposing a prison sentence for the sole reason of illegal stay is no longer possible, and because this is the main condition enabling placement in police custody, ${ }^{21}$ placement of aliens in police custody for the sole reason of illegal stay is unlawful. The CJEU's decisions have not expressly stated that the application of police custody regimes to third-country nationals is unlawful: this is the main contribution of the French Court of Cassation decisions of 5 July 2012. ${ }^{22}$

Although the Court of Cassation's decisions have been strongly acclaimed by defendants of aliens' rights, these decisions have caused political and legal problems over procedural issues.

On a political level, the government ${ }^{23}$ has expressed concerns about the effectiveness of its removal programme. It has argued that without a mechanism providing for a period of specific detention to allow the identities of aliens suspected of irregular stay to be verified, the government objective of fighting irregular immigration would not be achievable. ${ }^{24}$ Indeed, during such a specific detention period, public authorities would be able to coordinate their efforts through the issuance of an order of removal and the consequent placement in an administrative detention centre. ${ }^{25}$

The government intervened immediately after the decisions handed down by the Court of Cassation in 2012. On the one hand, it acknowledged the authority of these decisions by publishing official instructions to administrative and police officers to comply with the prohibition on the placement of aliens in police custody simply for being in the country illegally. ${ }^{26}$ On the other hand, the Interior Minister submitted a bill to the Senate on 28 September 2012 establishing special detention proceedings to allow the verification of the identity and legality of stay of third-country nationals in France. ${ }^{27}$ Following a short

\footnotetext{
${ }^{20}$ Hassen El Dridi, above n 7, 62; Achughbabian, above n 8, 50.

${ }^{21}$ Article 63 French Code of Criminal Procedure.

22 Cass. 1re civ., 5 July 2012, above n 3.

${ }^{23}$ The current government was formed following the election of Mr François Hollande as President of the Republic in May 2012.

24 Interior Minister Mr Manuel Valls's speech at the National Assembly, 11 December 2012 <http://www.interieur.gouv.fr/Le-ministere/Manuel-Valls/Interventions-du-Ministre/Projet-de-loi-relatif-a-laretenue-pour-verification-du-droit-au-sejour-et-modifiant-le-delit-d-aide-au-sejour-irregulier> accessed 23 May 2014.

${ }^{25}$ Both the order of removal and the order of placement in an administrative detention centre are issued by the prefectural authority, the Préfet (article 72 of the French Constitution defines the competences and roles of the Préfet as a representative of the central government).

${ }^{26}$ Interior Minister, Circular, 6 July 2012.

${ }^{27}$ Interior Minister, Bill n ${ }^{\circ}$ 789, 28 September 2012 < http://www.senat.fr/leg/pj111-789.html> accessed 24 May 2014.
} 
discussion and with limited amendments, the French Parliament adopted the bill on 31 December 2012 as Law no 2012-1560. ${ }^{28}$ The law aims to take into account the legal consequences of the decisions of the First Civil Chamber of the Court of Cassation of 5 July 2012 and to reform the regime for the detention of aliens in France. The special detention can last for sixteen hours. ${ }^{29}$ At the end of this specific period, third-country nationals can be either released (if they are found to be staying legally in France) or placed in an administrative detention centre to await expulsion or deportation.

The bill thus relates to detention with a view to expulsion or deportation but not to detention upon arrival or the detention of asylum seekers under the Dublin II regulation. ${ }^{30}$ This new procedure is not particularly innovative and very much resembles in substance the placement of suspected criminals in police custody. Aliens are arrested by police officers and are placed in police cells while the same police officers verify their identity and situation in terms of immigration and asylum law. ${ }^{31}$ However, the protection of the human rights of detainees under this special procedure is less effective than was formerly the case under the criminal code on police custody. ${ }^{32}$

The Court of Cassation's decisions have also created some legal and procedural problems. First, the Court adopted a slightly different approach ${ }^{33}$ in its interpretation of the CJEU's ${ }^{34}$ decisions. ${ }^{35}$

Second, there was a noteworthy lack of specific procedures for verifying the identity of aliens by the police from the time of the adoption of the Court of Cassation's decisions to the time of the adoption of Law no. 2012-1560. The French legal system during that period had no specific procedures for the identification of illegally resident aliens ${ }^{36}$.

Third, the legislative reform, which integrates the main findings of the Court of Cassation's decisions, fails to guarantee respect for fundamental rights. By introducing new proceedings that are less respectful of fundamental rights than those relating to police custody, ${ }^{37}$ the legislative reform has failed to truly improve the highly criticised detention scheme in France. ${ }^{38}$ One could therefore ask whether aliens' situation in France was not better before the intervention of the Court of Cassation, and by extension, the CJEU's decisions of 2011. The Court of Cassation decisions of 5 July 2012 have contributed to the transformation of detention from an extraordinary measure of last resort into an ordinary tool for combating illegal immigration, and the law of 31 December 2012 reflects this approach.

\footnotetext{
${ }^{28}$ Law 2012-1560, 31 December 2012, OJ 1 January 2013.

${ }^{29}$ Article L611-1-1 Code on the Entry and Residence of Foreigners and the Right of Asylum.

${ }^{30}$ For a comprehensive typology of detention in Europe, see Elspeth Guild, 'A Typology of Different Types of Centres for Third Country Nationals in Europe' (2006) European Parliament Briefing Paper < http://www.europarl.europa.eu/RegData/etudes/note/join/2006/378268/IPOL-LIBE_NT(2006)378268_EN.pdf> accessed 23 May 2014.

${ }^{31}$ Article L611-1-1, above n 29.

${ }^{32}$ See Section 4 below.

${ }^{33} \mathrm{~S}$ Slama, 'Epilogue d'une saga judiciaire sur la garde à vue pour séjour irrégulier' [2012] D 2001.

${ }^{34}$ Some authors argue that the CJEU's position is not completely straightforward. See Costello, 'Human Rights and the Elusive Universal Subject', above n 11, 295, and also the discussion in Section 3 below.

${ }^{35}$ See Section 3 below.

${ }^{36}$ See Section 4 below.

${ }^{37}$ See Section 4 below.

${ }^{38}$ Slama, above n 33. G Poissonnier, 'Etranger en situation irrégulière : conditions de la garde à vue' [2012] $D$ 1997.
} 
This article critically analyses the decisions of France's highest court in light of European Union legislation and case law. To examine these decisions fully, a critical analysis of the legal framework of police custody and detention in France is first provided. The argument is then advanced that the Court of Cassation decisions reflect European case law only partially, or even inaccurately. The influence and consequences of these decisions on legislative reform are then discussed. Finally, conclusions are drawn on the balancing of individual rights and public interest by the French judicial authorities on issues relating to aliens' rights.

\section{A legal framework reinforcing the criminalisation of migration in France}

The part of the French legal system concerning police detention was subject to an important general reform in $2011 .{ }^{39}$ With the aim of reducing the prevalence of detention, the French legislator introduced a general condition of validity for the use of police custody, namely, a direct relationship between the decision to place someone in police custody and the punishability of the criminal offence by a sentence of imprisonment. ${ }^{40}$ Before the reform, the use of police detention for the purposes of preliminary enquiries was not subject to this condition.

The 2011 legislation reinforced the restrictions on the use of police detention. It provided that this type of detention should only be conceived of as a means to achieve one of the legal objectives of the criminal code, such as guaranteeing that an individual suspected of committing a criminal offence does not abscond before being presented to the Prosecutor. ${ }^{41}$ As was pointed out in the report of the Senate of 14 April 2011 concerning the new law on police custody, the reform aimed to fulfil the requirements of proportionality and the balancing of rights. ${ }^{42}$ Some additional guarantees were provided or reinforced, notably the right to the assistance of counsel from the start of detention and the right to remain silent. The reform was initiated after the European Court of Human Rights condemned the French system of police custody in $2010 .^{43}$

The changes to the police custody system introduced by the reform also apply to the detention of aliens by the police. Article L621-1 of the Code on the Entry and Residence of Foreigners and the Right of Asylum as it stood before the law of 31 December $2012^{44}$ provided that the offence of illegal entry into the territory and of illegal residence in France could carry a punishment of up to one year of imprisonment. ${ }^{45}$ Consequently, the placement

\footnotetext{
${ }^{39}$ Law 2011-392, 14 April 2011, OJ 8915 April 2011.

${ }^{40}$ Article 62-2 Code of Criminal Procedure.

${ }^{41}$ Article 62-2 (2) Code of Criminal Procedure.

${ }^{42}$ Senate, Report n ${ }^{\circ} 315$ of Mr François Zochetto, 16 February 2011.

${ }^{43}$ Brusco v France, App no 1466/07 (ECHR, 14 October 2010).

${ }^{44}$ Law 2012-1560, above n 28.

45 Article L621-1 Code on the Entry and Residence of Foreigners and the Right of Asylum provided that 'Any foreign national who enters into or resides in France in breach of the provisions of Articles L.2111 and L.3111 or who has remained in France in excess of the period authorised by visa shall be punished to a term of imprisonment of one year and a fine of $€ 3,750$. The court may moreover prohibit a foreign national who has been convicted of the offence from entering into or residing in France for a period of up to three years. The geographical ban shall automatically entail the deportation of the convicted individual, if appropriate, upon conclusion of his term of imprisonment'. This provision was repealed by Law No. 2012-1560 (ibid).
} 
of aliens in police custody on the sole ground of illegal stay was lawful under French criminal law.

This was also the position adopted by the Constitutional Council, which analysed the question from the perspective of constitutional law only. ${ }^{46}$ Evading the issue of the compatibility of such legislation with the specificities of EU law and framing the question on a strict constitutional basis, ${ }^{47}$ the Constitutional Council held that there was no incompatibility between the statute and the Constitution. It even went so far as to state that 'having regard to the nature of the offence for which they have been established, the penalties thereby laid down, which are not manifestly disproportionate, do not violate Article 8 of the 1789 Declaration' ${ }^{48}$

The main criticism that can be formulated of French legislation in this regard is of the treatment of irregularly staying aliens as criminals, which is explicit in the categorisation of illegality of stay as a criminal offence. However, it should not necessarily be considered that once immigration detention is placed within the jurisdiction of administrative law and not within criminal law, there is no more room for the criminalisation of migration.

Provisions for immigration detention can have either a criminal or an administrative nature. However, even administrative sanctions, including detention, show an increasing resemblance to criminal sanctions. As has been pointed out by Professor Elspeth Guild, 'concern regarding the use of criminal sanctions, or administrative sanctions which mimic criminal ones (such as detention), in respect of border and immigration control issues has been rising for some time ${ }^{49}$ in many European countries. In France, irregular immigrants can no longer be detained in police custody since the decision of the First Civil Chamber of the Court of Cassation of 5 July 2012. ${ }^{50}$ Nevertheless, the new 'administrative' procedure

\footnotetext{
${ }^{46}$ C. C., $\mathrm{n}^{\circ}$ 2011-217QPC, Mohammed Alki B, 3 February 2012. The Court of Cassation referred a question concerning the conformity of Article 621-1 of the Code on the Entry and Residence of Foreigners and the Right of Asylum and the rights and freedoms guaranteed by the Constitution to the Constitutional Council under the priority preliminary ruling procedure. Article 61-1 of the Constitution provides any person involved in legal proceedings with the right to argue that a statutory provision infringes rights and freedoms guaranteed by the Constitution. An application for a priority preliminary ruling can be lodged by any person before any judicial authority, which then refers the question of constitutionality to the Conseil d'Etat or to the Court of Cassation. These Highest Courts then refer the application to the Constitutional Council, which has jurisdiction to judge the constitutionality of any statutory provision provided that the conditions of admissibility are respected. These conditions are established by article 61-1 of the Constitution (firstly, the challenged statutory provision must apply to the litigation or proceedings involved, or be the basis of such proceedings; secondly, the challenged statutory provision must not have been previously found to be constitutional by the Constitutional Council; thirdly, the issue raised is a new one or is of a serious nature). For information, <http://www.conseilconstitutionnel.fr/conseil-constitutionnel/english/priority-preliminary-rulings-on-the-issue-ofconstitutionality/priority-preliminary-rulings-on-the-issue-of-constitutionality.48002.html> accessed 23 May 2014. See also D Rousseau, Droit du contentieux constitutionnel (Montchrestien 2010); D Rousseau and B Mathieu, Les grandes décisions de la question prioritaire de constitutionnalité (LGDJ 2013) ; JH Stahl and C Maugue, La question prioritaire de constitutionnalité ( ${ }^{\text {nd }}$ edition Dalloz 2012).

${ }^{47}$ A Levade, 'QPC et directive "retour": retour en arrière jurisprudentiel ?' (2012) 8 JCP G 350; V Tchen, 'Séjour irrégulier: constitutionnalité de délit' (2012) DA 4, 33; JB Perrier, 'Constitutionnalité et inconventionalité de la peine prévue pour délit de séjour irrégulier : une opposition à préciser’ (2012) 92 RFDC 889.

${ }^{48}$ C. C., $\mathrm{n}^{\circ}$ 2011-217QPC, Mohammed Alki B, above $\mathrm{n} 46$.

${ }^{49}$ E Guild, 'Criminalisation of Migration in Europe: Human Rights Implication' (2009) Council of Europe Commissioner for Human Rights Issue Paper, 5 <www.commissioner.coe.int> accessed 23 May 2014.

${ }^{50}$ Cass. 1re civ., 5 July 2012, above n 3.
} 
established by the Law of 31 December $2012^{51}$ borrows its main features from the police custody system. ${ }^{52}$

Accordingly, it seems that detention is not anymore an individual measure of last resort but a large-scale instrument extensively used by different countries. ${ }^{53}$ This is confirmed by the situation in France, notably after the introduction of the new special detention procedure with the Law of 31 December 2012. ${ }^{54}$ Immigration detention reflects the stereotype so strongly embedded in the popular imagination of the alien as a dangerous offender. ${ }^{55}$

In France some commentators have argued that the 'confusion with criminal law fades away ${ }^{56}$ through the influence of EU law after the decisions of the Court of Cassation, but there is no certainty that the reorganisation of detention under administrative law will be sufficient to put an end to the criminalisation of migration. ${ }^{57}$ On the contrary, the trend of the criminalisation of migration is confirmed by the fact that irregular stay and irregular entry into French territory are still considered criminal offences. ${ }^{58}$

\section{A partial and idiosyncratic implementation of European case law by the French Court of Cassation}

Although the Court of Cassation's decisions reached the same results as the CJEU's decisions on the detention of undocumented immigrants, the French court adopted a slightly different reasoning. ${ }^{59}$ As emphasised by Serge Slama, 'the First Civil Chamber of the Court of Cassation's decisions diverge, for mysterious reasons, from the legal opinion of the Criminal Chamber of this Court and also from the ordinary meaning and purpose of the CJEU's decision in Achughbabian'. ${ }^{6}$

The CJEU held that Directive 2008/115 precludes national legislation imposing a prison sentence on an illegally staying third-country national during the return procedure. ${ }^{61}$ According to the CJEU, the effectiveness of the return procedure established by the Directive

\footnotetext{
${ }^{51}$ Law 2012-1560, above n 28.

${ }^{52}$ See Section 4 below.

${ }^{53} \mathrm{G}$ Cornelisse, Immigration Detention and Human Rights. Rethinking Territorial Sovereignty (Martinus Nijhoff 2010) 24.

${ }^{54}$ See Section 4 below.

${ }^{55}$ L Muchielli, 'Immigration et délinquance: réalités, amalgames et racismes' (2012) in GISTI, Immigration, un régime pénal d'exception < http://www.gisti.org/publication_pres.php?id_article=2781> accessed 23 May 2014. For a study of the perception of aliens in host societies, see Bridget Anderson, Us and Them? The Dangerous Politics of Immigration Control (OUP 2013).

${ }^{56}$ Danet, above n 10, 621.

${ }^{57}$ The same observation applies to the criminalisation of migration in the United Kingdom, see M Bosworth, 'Human rights and immigration detention in the United Kingdom' in MB Dembour and T Kelly (eds.), Are Human Rights for Migrants? Critical Reflections on the Status of Irregular Migrants in Europe and the United States (Routledge 2011) 165, 170.

${ }^{58}$ Articles L621-2 and L624-1 Code on the Entry and Residence of Foreigners and the Right of Asylum. See Sections 3 and 4.

${ }^{59}$ Cass. 1re civ., 5 July 2012, above n 3.

${ }^{60}$ Slama, above n 33.

${ }^{61}$ Hassen El Dridi, above n 7, 62. Achugbabian, above n 8, 50.
} 
would be undermined if an undocumented immigrant were retained in prison during the procedure, rather than being effectively removed from the territory of the Member State. ${ }^{62}$

However, the CJEU has also established that the Directive does not preclude criminal penalties being imposed by domestic law, as long as these respect fundamental rights. ${ }^{63}$

It is true that the Court is more permissive in this respect than its advocate general would have allowed for in his opinion. ${ }^{64}$ As emphasised by Cathryn Costello, 'the Court leaves more leeway for national criminal measures' in practice. ${ }^{65}$ The Court could have gone further and imposed that the adoption of criminal measures and detention in general should be considered a priori as opposed to EU legislation.

Some, such as Professor Jean-Yves Carlier, have argued that the Court, in the El Dridi and in Achughbabian cases, has indirectly and very diplomatically affirmed that the criminalisation of the irregular stay of aliens is condemned under the guise of the effectiveness of removals. ${ }^{66}$ It is difficult to agree with this statement.

It is submitted that the Court seems rather to reaffirm the importance of state sovereignty ${ }^{67}$ concerning the autonomy of states to decide not only on their own criminal policies and legislation, but also on issues related to the management and control of migration. Moreover, this approach was reaffirmed last December by the CJEU in the case of Md Sagor, ${ }^{68}$ which concerned, as in the El Dridi case, Italian legislation qualifying illegal stay as a criminal offence and imposing pecuniary penalties. ${ }^{69}$ The Court expressly recognises that "nothing in Directive 2008/115 precludes the removal referred to in Article 8(1) of that Directive from being carried out in the context of criminal proceedings' ${ }^{70}$ Accordingly, the criminalisation of migration seems to be considered by the CJEU as a matter of domestic policy so long as it does not interfere with the efficacy of removals in the sense of the Returns Directive. As is well defined by Rosa Rafaelli in a commentary on the Achughbabian case, 'member states

${ }^{62}$ Hassen El Dridi, above n 7, 53. Achugbabian, above n 8, 33.

${ }^{63}$ Achughbabian, above n 8, 48.

${ }^{64}$ Hassen El Dridi, above n 7, Opinion of AG Mazák, paras 43-49.

${ }^{65}$ Costello, 'Human Rights and the Elusive Universal Subject', above n 11, 298.

${ }^{66}$ JY Carlier, 'La libre circulation des personnes dans et vers l'Union européenne: Année 2011' (2012) 20 Journal de Droit Européen 85, 86.

${ }^{67}$ On the concept of sovereignty in the area of migration, see Cornelisse, Immigration Detention and Human Rights, above n 53, 229. G Cornelisse, 'A New Articulation of Human Rights, or Why the European Court of Human Rights Should Think beyond Westphalian Sovereignty' in MB Dembour and T Kelly (eds.), Are Human Rights for Migrants? Critical Reflections on the Status of Irregular Migrants in Europe and the United States (Routledge 2012).

${ }^{68}$ Case C-430/11 Criminal proceedings against Md Sagor [2012] OJ C 26, 13 [47]. M Aubert, E Broussy and $\mathrm{H}$ Cassagnabère, 'Chronique de jurisprudence de la CJUE. Séjour irrégulier d'un ressortissant d'un Etat tiers Sanctions pénales' [2013] AJDA 337.

${ }^{69}$ The CJEU reaffirms that 'Directive 2008/115 concerns only the return of illegally staying third-country nationals and is thus not designed to harmonise in their entirety the rules of the Member States on the stay of foreign nationals. Therefore, that Directive does not preclude the law of a Member State from classifying an illegal stay as an offence and laying down criminal sanctions to deter and penalise such an infringement' and deems that pecuniary penalties that can be permuted with expulsion are in line with the aims of the Returns Directive. However, the replacement of a pecuniary penalty by a measure of home stay is seen as contrary to the Directive. Md Sagor, above n 68, 31.

70 ibid 39. 
may criminalise illegal entry or stay, and they may place third-country nationals in detention in order to determine whether their stay is lawful'. ${ }^{71}$

In any event, the case of Achughbabian demonstrated the peculiar practice of the French authorities in fighting illegal immigration. Undocumented immigrants were firstly placed in police custody for up to 48 hours and then placed in detention centres. ${ }^{72}$ Placement in police custody was only possible under domestic law because it referred to a criminal offence that was punishable with a one-year prison sentence. The offence was the illegality of the stay of third-country nationals in French territory. ${ }^{73}$ In this case, the potential application of the penal sanction of one year of imprisonment would jeopardise the achievement of the objectives pursued by Directive 2008/115. ${ }^{7475}$

Although Member States have great autonomy to adopt their own criminal legislation in the area of illegal immigration, ${ }^{76}$ they must also comply with EU law. ${ }^{77}$ Thus, Member States can impose "coercive measures ${ }^{78}$ on third-country nationals to achieve their efficient removal under the returns procedure. However, they cannot prevent the removal from being effectively realised in practice. The content of these coercive measures has been interpreted by the CJEU as being related to measures leading to the achievement of the effective removal of undocumented immigrants. ${ }^{79}$

In the El Dridi case, the CJEU established that Member States should apply the returns procedure in conformity with its various steps. Firstly, priority should be given to voluntary departure. ${ }^{80}$ Secondly, if this measure fails, then the State can start forced removal proceedings. ${ }^{81}$ The coercive measures that Member States can then adopt should respect the

\footnotetext{
${ }^{71}$ R Rafaelli, 'Illegal Migration: the "Returns" Directive in the Recent Case-law of the ECJ' (2012) Blog European Area of Freedom Security and Justice < http://eafsj.org/2012/03/07/illegal-migration-the-returnsdirective-in-the-recent-case-law-of-the-ecj/> accessed 23 May 2014.

${ }^{72}$ For an interpretation of the period of detention and the concept of reasonable prospect of removal, see Case C-357/09 PPU Said Shamilovich Kadzoev [2009] ECR I-11189. Costello, 'Human Rights and the Elusive Universal Subject', above n 11, 292-295.

${ }^{73}$ Article L621-1 Code on the Entry and Residence of Foreigners and the Right of Asylum.

${ }^{74}$ Preamble, Directive 2008/115.

${ }^{75}$ Hassen El Dridi, above n 7, 33. Achughbabian, above n 8, 43.

${ }^{76}$ The European Court of Human Rights has also adopted a similar position, holding that 'States enjoy an undeniable sovereign right to control aliens' entry into and residence in their territory'. Abdulaziz, Cabales and Balkandali v United Kingdom App no 9214/80 9473/81 9474/81 (ECtHR, 28 May 1985); Amuur v France App no 19776/92 (ECtHR, 25 June 1996); Chahal v United Kingdom App no 22414/93 (ECtHR, 15 November 1996); Saadi v United Kingdom App no 13229/03 (ECtHR, 29 January 2008). For a critical approach of the European Court's case-law see: V Moreno-Lax, 'Beyond Saadi v UK: The "Necessity" Requirement for Administrative Detention of Asylum Seekers in the EU' Centre for Philosophy of Law, Université Catholique de Louvain Working paper series REFGOV-FR-31 <http://refgov.cpdr.ucl.ac.be> accessed 23 May 2014. V Moreno-Lax, 'Beyond Saadi v UK: Why the 'Unnecessary' Detention of Asylum Seekers is Inadmissible under EU Law' (2011) 5 Human Rights and International Legal Discourse 166. C Costello, 'Courting Access to Asylum in Europe: Recent Supranational Jurisprudence Explored' (2012) 12 HRLR 287.

${ }^{77}$ Articles 77 to 80 TFEU.

${ }^{78}$ Article 8 Directive 2008/115.

79 Achughbabian, above n 8, 36.

${ }^{80}$ Article 7 Directive 2008/115.

${ }^{81}$ Article 8 Directive 2008/115.
} 
gradation imposed by the Directive. In other words, States should adopt the least coercive measures first and leave detention as a measure of last resort. ${ }^{82}$

The CJEU has made explicit its view that 'Directive 2008/115 sets out specifically the procedure to be applied by each Member State for returning illegally staying third-country nationals and fixes the order in which the various, successive stages of that procedure should take place. $^{, 83}$

It is therefore clear that the CJEU insists on gradation in the adoption of coercive measures. The first step obliges Member States to issue a return decision against a thirdcountry national staying illegally in their territory. The undocumented immigrant is then given a period of seven to thirty days to comply voluntarily with this obligation to return. ${ }^{84}$ The second step in the procedure allows Member States 'to carry out the removal by taking all necessary measures including, where appropriate, coercive measures, in a proportionate manner and with due respect for, inter alia, fundamental rights'. ${ }^{85}$ These measures apply in particular circumstances, such as where there is a risk of absconding. ${ }^{86}$

Unequivocally, the Court maintains that 'Member States must carry out the removal using the least coercive measures possible. It is only where, in the light of an assessment of each specific situation, the enforcement of the return decision in the form of removal risks being compromised by the conduct of the person concerned that the Member States may deprive that person of his liberty and detain him'. ${ }^{87}$

The aim behind the CJEU's reasoning is the effective enforcement of the return decision. Member States should comply with the requirements of EU law, notably the effectiveness of the objectives set down in Directive 2008/115. Moreover, the principle of proportionality must be respected by domestic authorities in adopting coercive measures to enforce a return decision. ${ }^{88}$ It is clear that gradation in the adoption of such measures develops from a measure that is least restrictive of a person's freedom, namely, the grant of up to thirty days for voluntary departure, to the most restrictive one: detention. ${ }^{89}$

Nonetheless, the French Court of Cassation has not understood this gradation in the same way that the CJEU did. The First Civil Chamber of the Court of Cassation ${ }^{90}$ interpreted the coercive measures provided by article 8 of Directive 2008/115 as independent of and alternative to the measure of detention. The Court of Cassation considers that 'Directive 2008/115 precludes national legislation from imposing a prison sentence for illegal stay, as this legislation can lead, for this sole reason, to the imprisonment of a third-country national who does not comply with a decision of voluntary departure from the national territory, when either he or she has not been previously subjected to one of the coercive measures referred to

\footnotetext{
${ }^{82}$ Article 15 (1) Directive 2008/115 provides that 'unless other sufficient but less coercive measures can be applied effectively in a specific case, Member States may only keep in detention a third-country national who is the subject of return procedures in order to prepare the return and/or carry out the removal process'.

${ }^{83}$ Hassen El Dridi, above n 7, 34.

${ }^{84}$ Article 7 Directive 2008/115.

${ }^{85}$ Hassen El Dridi, above n 7, 38.

${ }^{86}$ Article 15 (1) a Directive 2008/115.

${ }^{87}$ Hassen El Dridi, above n 7, 39.

88 ibid 43.

${ }^{89}$ ibid 41.

${ }^{90}$ Cass. 1re civ., 5 July 2012, above n 3.
} 
in article 8 of the Directive, or when he or she has been subjected to detention but the maximum length of detention has not yet expired'. ${ }^{91}$

This alternative understanding of the sequential order of the adoption of coercive measures clearly contradicts the CJEU's cumulative understanding of the topic, as described. More importantly, it has led to the trivialisation of the use of detention by the French authorities, in spite of the gradation imposed by the CJEU. In other words, the Court of Cassation's findings legitimise the use of detention orders in the first stage of the procedure, ${ }^{92}$ regardless of the CJEU's clear statement that detention should be seen as a measure of last resort. This is the most regrettable effect of the French Court's decisions.

This divergence of interpretation from the CJEU has led to unsatisfactory situations in practice. On the one hand, placement in police custody is now definitely prohibited in France. On the other hand, the well-established practice of taking undocumented immigrants to police stations to verify their identity, followed by automatic placement in a detention centre, has been maintained. This practice was accepted by the Minister of Justice's Circular of 6 July $2012,{ }^{93}$ and has now become the rule as established by the law of 31 December $2012 .{ }^{94}$ This legislation establishes a particular procedure for the verification of aliens' identity that, despite similarities with the ordinary procedure of police custody, can be seen as less protective of fundamental rights, as will be discussed.

\section{The consequent trivialisation of detention by legislative reform in France}

The need for legislative reform of the whole system of detention and placement in police custody of undocumented immigrants was highlighted by the Minister of Justice and the Interior Minister in the aftermath of the decisions of the First Civil Chamber of the Court of Cassation. ${ }^{95}$ These decisions have made impossible the placement in police custody of aliens on the sole ground of illegal stay.

The Minister of Justice proposed some alternative legal instruments as a substitute for police custody proceedings in the Circular of 6 July 2012, but these instruments have not been sufficiently effective. The Minister considered in her Circular the alternative options of a voluntary hearing proceeding and the procedure of identity verification provided by article 78-3 of the Code of Criminal Procedure. These procedures were used by police officers

\footnotetext{
${ }^{91}$ ibid. (emphasis added). The French version is as follows. 'Mais attendu qu'il résulte de la jurisprudence de la Cour de justice de l'Union européenne (arrêts du 28 avril 2011, C-61/PPU, et du 6 décembre 2011, C-329/11) que la directive 2008/115/CE s'oppose à une réglementation nationale réprimant le séjour irrégulier d'une peine d'emprisonnement, en ce que cette réglementation est susceptible de conduire, pour ce seul motif, à l'emprisonnement d'un ressortissant d'un pays tiers, lorsque ce dernier, non disposé à quitter le territoire national volontairement, soit n'a pas été préalablement soumis à l'une des mesures coercitives prévues à l'article 8 de cette directive, soit, a déjà fait l'objet d'un placement en rétention, mais n'a pas vu expirer la durée maximale de cette mesure'.

92 This is, for instance, the approach adopted by the government: Law 2012-1560, above n 28.

${ }^{93}$ Minister of Interior, Circular, 6 July 2012.

${ }^{94}$ Law 2012-1560, above n 28.

${ }^{95}$ Cass. 1re civ., 5 July 2012, above n 3.
} 
between July 2012 and December 2012. Both, however, were markedly inefficient in achieving the goals that the Minister had set out. ${ }^{96}$

A voluntary hearing is a procedure that allows police officers to take statements from anyone with relevant information about an ongoing criminal case. Its two main characteristics are that the statement should be made voluntarily and that the concerned party is free to leave the police station at any time. Consequently, it implies the voluntary surrender of undocumented immigrants. It can be argued that this procedure is not adapted to the situation in practice. Indeed, it is hard to imagine that an undocumented immigrant would voluntarily surrender with the intention of declaring his or her illegal status. It is equally difficult to conceive that an immigrant would declare an illegal stay and would freely leave the police station immediately afterwards. Therefore, this procedure cannot be considered a valid alternative means of enforcing the main goal of Directive 2008/115, which is the effective return of illegally staying immigrants.

The procedure for identity verification established by article 78-3 of the Code of Criminal Procedure can be considered inadequate on account of its brevity. The procedure allows the detention of an individual in a police station for four hours only. During this short period the police authorities should not only verify the illegality of stay of an alien but also, eventually, ask the prefectural administrative authority to issue an order for removal. Otherwise, the alien should be released at the end of the four hours. The police and administrative prefectural services would need to co-ordinate extremely well with each other to make this procedure effective.

Hence, these two alternative procedures were obviously not sufficiently efficient to deal with the situation of the illegally staying third-country nationals in France. The need to reorganise the whole system of return procedures in France was urgent and undisputable. In response to this situation of a practical legal vacuum, a bill was submitted by the Interior Minister to the Senate on 28 September $2012^{97}$ and adopted as law by Parliament on 31 December 2012. ${ }^{98}$

This law establishes a special detention procedure with the sole goal of determining the identity and legality of stay of aliens in France. An alien's situation is scrutinised by a police officer at the police station for a maximum of sixteen hours. The prosecutor is informed by the police officer of the ongoing detention. Basic guarantees should be assured, including the possibility for the individual to ask for the assistance of a lawyer and an interpreter, and for a medical examination. ${ }^{99}$

These special proceedings apply to irregular immigrants in general. ${ }^{100}$ Asylum seekers are in principle not covered by these provisions, and their identity and legality of stay may only be determined outside of a police station. ${ }^{101}$ However, two situations can be considered: on the one hand, the case of asylum seekers whose claims are under examination; on the other hand, the position of asylum seekers whose applications have been rejected.

\footnotetext{
${ }^{96}$ B Francos, 'Un avis cinglant envers le projet de loi qui heurte les droits des étrangers et les exigences européennes' (2012) Lettre Actualités Droits-Libertés <revdh.org> accessed 24 May 2014.

${ }^{97}$ Minister of Interior, Bill $\mathrm{n}^{\circ} 789$, above $\mathrm{n} 27$.

${ }^{98}$ Law 2012-1560, above n 28.

99 Article L611-1-1 Code on the Entry and Residence of Foreigners and the Right of Asylum.

${ }^{100}$ Article L611-1-1 Code on the Entry and Residence of Foreigners and the Right of Asylum.

${ }^{101}$ Article L611-1 Code on the Entry and Residence of Foreigners and the Right of Asylum.
} 
First, asylum seekers who can prove that their claim is under examination should not be, $a$ priori, placed in detention under this specific set of rules. The opposite would be, in principle, contrary to article 31 (1) of the Geneva Convention Relating to the Status of Refugees. ${ }^{102}$ This provision establishes that 'States shall not impose penalties, on account of their illegal entry or presence, on refugees who, coming directly from a territory where their life or freedom was threatened in the sense of article 1, enter or are present in their territory without authorisation, provided they present themselves without delay to the authorities and show good cause for their illegal entry or presence'.

However, the term 'penalties' is not defined by article 31 (1). The question then arises of how to define the boundaries of the material scope of this article; in other words, it is important to define if it applies only to criminal sanctions or if it also applies to administrative penalties, such as administrative detention. ${ }^{103}$ The French version of the text refers to 'sanctions pénales', which could lead to a narrow interpretation of the term in the strict context of criminal penalties only. The English version would, on the contrary, allow for a wider interpretation of the term, perhaps including administrative penalties within its scope. The system established by the French law relates to administrative proceedings only, and thus falls outside of the scope of article 31 (1) of the Geneva Convention, unless the concept of 'penalties' is interpreted in a wider way to also include administrative measures that are very similar to criminal penalties. ${ }^{104}$

As highlighted by Professor Goodwin-Gill, 'the object and purpose of the protection envisaged by Article 31 (1) of the 1951 Convention is the avoidance of penalization on account of illegal entry or illegal presence. An overly formal or restrictive approach to defining this term will not be appropriate, for otherwise the fundamental protection intended may be circumvented and the refugee's rights withdrawn at discretion'. ${ }^{105}$ Consequently, administrative detention, such as that provided by the French Law of 31 December 2012, would fall within the scope of article 31 (1). In this sense, the French authorities should refrain from detaining asylum seekers while their asylum claim is under examination.

Nevertheless, another provision of the Geneva Convention, article 31 (2), provides that refugees can be subject to restrictions on their freedom of movement if these are seen as 'necessary'. ${ }^{106}$ The necessity of identity verification could therefore be supported by reasons relating to the maintenance of public order. ${ }^{107}$ The French authorities could then evoke public order concerns to justify the use of a special sixteen-hour detention procedure to verify the identity and legality of stay of asylum seekers. The measure would need to be necessary and

\footnotetext{
${ }^{102}$ Convention Relating to the Status of Refugees, 28 July 1951, 189 U.N.T.S. 137.

${ }^{103}$ G Goodwin-Gill, 'Article 31 of the 1951 Convention Relating to the Status of Refugees: Non-Penalization, Detention, and Protection', in Erika Feller, Volker Turk and Frances Nicholson (eds.) Refugee Protection in International Law: UNHCR's Global Consultations on International Protection (CUP 2003) 185.

${ }^{104}$ For a critical discussion of the detention of asylum seekers, see Costello, 'Human Rights and the Elusive Universal Subject', above n 11, 275.

${ }^{105}$ Goodwin-Gill, above n 103, 194.

106 Article 31 (2) Convention Relating to the Status of Refugees.

107 The UNHCR revised the guidelines on the applicable criteria and standards relating to the detention of asylum seekers in October 2012. Guideline 3 now establishes that 'Detention must be in accordance with and authorised by law'. Guideline 4.1 provides that 'Detention is an exceptional measure and can only be justified for a legitimate purpose'. The protection of public order is one of the legitimate purposes put forward by guideline 4.1.1. UNHCR, Guidelines on the Applicable Criteria and Standards Relating to the Detention of Asylum Seekers <http://www.unhcr.org/refworld/docid/503489533b8.html> accessed 23 May 2014. For a commentary on these new guidelines, see Alice Edwards, 'Detention under scrutiny' (2013) 44 FMR 4.
} 
reasonable, at the least in terms of the duration. Accordingly, asylum seekers would only be submitted to this special detention procedure exceptionally.

Second, asylum seekers whose applications have been rejected and who have not yet left the French territory can be subjected to the new proceedings established by French law to verify their identity and legality of stay. In a way, these 'former asylum seekers' have become irregular immigrants, sensu stricto, due to the rejection of their asylum claim.

Apart from establishing these specific detention proceedings for verifying identity and legality of stay, the French law of 31 December 2012 also maintains the criminal offence of illegal entry into the territory ${ }^{108}$ and creates a new criminal offence for illegal stay. ${ }^{109}$ The latter provides the punishment of one year of imprisonment and the payment of a fine of 3,750 Euros. It only applies to situations of illegal stay when coercive measures to achieve removal have been previously pronounced by the authorities and have failed. The law seems not to clearly distinguish between the administrative and criminal domains, and hence administrative measures coexist with criminal measures. As has been discussed, this clearly indicates the criminalisation of migration in France. ${ }^{110}$

Scholars and human rights activists strongly criticised the bill when it was proposed, arguing that it would contribute to the further marginalisation of aliens in France. ${ }^{111}$ Indeed, the bill of the Interior Minister and the law adopted by Parliament have several considerable gaps concerning the protection of the rights of detainees.

Firstly, the creation of this new procedure of detention of undocumented immigrants is very restrictive of individual rights. The National Consultative Commission on Human Rights pointed this out in a recommendation adopted on 22 November 2012. ${ }^{112}$ The Commission argued that it would be preferable to opt for a more proportionate and less coercive solution. ${ }^{113}$ Indeed, the systematic use of detention as a tool to manage the immigration influx and forced returns of irregular immigrants is abusive. As noted by Galina Cornelisse, 'just as with deportation, detention is a necessity for states that want to be seen to be 'in control' of their borders'. ${ }^{114}$ The use of migration detention in France can be seen as an effort to reassert the power of the State ${ }^{115}$ and to deter new waves of irregular immigration. The criminalisation of irregular entry and stay can also be seen as a clear sign sent to prospective irregular immigrants that France will not tolerate infractions of its immigration laws and will harshly treat those venturing into the territory irregularly.

\footnotetext{
${ }^{108}$ Article L621-2 Code on the Entry and Residence of Foreigners and the Right of Asylum.

${ }^{109}$ Article L624-1 Code on the Entry and Residence of Foreigners and the Right of Asylum.

${ }^{110}$ See Section 2 above.

${ }^{111}$ D Lochak, 'Publication de l'ouvrage "Immigration, un régime pénal d'exception", Lettre Actualités Droits-Libertés, 16 July 2012 <revdh.org> accessed 24 May 2014. French Professional Association of Magistrates, 'Observations about the government's proposal of creation of a especial detention procedure of verification of aliens' legality of stay' (2012) <www.syndicat-magistrature.org> accessed 23 May 2014. F Beguin and F Johannes, 'Une "retenue" de seize heures pour les sans-papiers' (Le Monde, 29 September 2012) 3 .

${ }^{112}$ CNCDH, Advisory Opinion, 22 November 2012 <www.cncdh.fr〉 accessed 24 May 2014.

${ }^{113}$ Ibid, 8. The Commission supported instead the modification of the existing procedure provided by article 78-3 of the Code of Criminal Procedure where, given the complexity of the situation and in exceptional circumstances, an extension of the initial four hours of detention is 'strictly necessary'.

${ }^{114}$ Cornelisse, Immigration Detention and Human Rights, above n 53, 238.

${ }^{115}$ On the situation in the United Kingdom, see Bosworth, above n 57, 171.
} 
Secondly, although some minimum guarantees are emphasised by the law, it nevertheless suffers from a lack of effective judicial oversight. Judicial control is placed under the authority of prosecutors, ${ }^{116}$ which are also members of the judiciary in the French legal system. However, due to their primary accusatory function, they cannot be considered impartial judges. Moreover, according to the National Consultative Commission on Human Rights, they are in practice overloaded with ordinary cases, making this control 'illusory'. ${ }^{117}$

The main criticism is that the judge of freedoms and detention, ${ }^{118}$ a major figure in the control of fundamental rights in any detention procedure in the French legal system, is entirely excluded from this new procedure. This judge is the only authority to have jurisdiction over detention matters in the French legal system. ${ }^{119}$ Nevertheless, on the matter of aliens' detention, he does not have access to the case before the end of the sixteen hours of detention. He only has jurisdiction to examine the situation of immigrants in two cases: after the adoption by the administrative authorities of a decision placing the alien in an administrative detention centre for up to 45 days; and after the adoption by the administrative authorities of a decision to place the alien under house arrest. ${ }^{120}$ Therefore, the analysis of the regularity of the detention proceedings escapes the jurisdiction of this judge during the first sixteen hours of detention.

Thirdly, the adopted legislation only provides that the alien should be informed of his or her rights in a language that he or she understands or "which it is reasonable to suppose that he or she understands'. ${ }^{121}$ Clearly, the vagueness of this provision may allow room for misinterpretation and the discretionary abuse of the law by police officers. ${ }^{122}$ Consequently, it would be impossible to claim the nullity of the procedure if the alien does not understand the language chosen by the police officer, insofar as the police officer's assessment that the alien would understand was 'reasonable'. This is in clear contradiction of article 5 (2) of the European Convention on Human Rights, which explicitly provides that 'Everyone who is arrested shall be informed promptly, in a language which he understands, of the reasons for his arrest and of any charge against him'. ${ }^{123}$ It needs to be noted that this French procedural aberration only applies to aliens detained under the new special regime of sixteen-hour detention for verification of identity and legality of stay. As far as placement in police custody is concerned, the rules are much clearer: information must be given in a language that the individual concerned fully understands, even if an interpreter is required to fulfil this legal obligation. ${ }^{124}$

Fourthly, the right to communicate with someone is considerably truncated in the newly adopted sixteen-hour detention procedure. Only the right to communicate with a member of the family or any other person is given to the undocumented immigrant placed in

\footnotetext{
${ }^{116}$ Article L611-1-1 Code on the Entry and Residence of Foreigners and the Right of Asylum.

${ }^{117} \mathrm{CNCDH}$, Advisory Opinion, above n 111, 8.

${ }^{118}$ The functions of judges of freedom and detention were created by the Law 2000-516 of the 15 June 2000 relating to the reinforcement of the protection of the principle of the presumption of innocence and of victims' rights (Law 2000-515, 15 June 2000, OJ 16 June 2000).

${ }^{119}$ Article 137-1 Code of Criminal Procedure.

${ }^{120}$ Articles L552-1 and L562-1 Code on the Entry and Residence of Foreigners and the Right of Asylum.

${ }^{121}$ Article L611-1-1 Code on the Entry and Residence of Foreigners and the Right of Asylum.

${ }^{122}$ This provision is in clear conflict with the UNHCR's guideline number 7 on the detention of asylum seekers, which establishes minimum procedural safeguards, above n 107.

${ }^{123}$ For an application by the European Court of Human Rights, see notably Shamayev and others v. Georgia and Russia App no 36378/02 (ECtHR, 12 October 2005).

${ }^{124}$ Article 63-1 Code of Criminal Procedure.
} 
detention. ${ }^{125}$ As emphasised by the National Consultative Commission on Human Rights, this new procedure is less protective of individual rights than the procedures for police custody or for detention in specialised centres. ${ }^{126}$ Charities and other non-governmental organisations that specialise in aliens' rights advocacy have been sidelined in this process, as they are not allowed to cooperate while the immigrant is being detained for the first sixteen hours, although their expertise would be very helpful to aliens in detention. Sometimes, because of a lack of information, these undocumented immigrants simply do not claim asylum or subsidiary protection, even though their situation meets the conditions of attribution of one of these legal statuses. Regrettably, such persons only have the support of charities and nongovernmental organisations once they are placed in detention centres. ${ }^{127}$

Finally, the right to counsel has been considerably reduced in the new detention procedure. Aliens can benefit from the assistance of a lawyer, but only a 30-minute interview is provided by the law. ${ }^{128}$ The final version of the bill adopted by Parliament adds that a lawyer can assist at an alien's hearings with police officers. The situation for placement in police custody is slightly different. After the legislative reform of $2011,{ }^{129}$ lawyers can assist individuals placed in police custody from the start of the procedure. ${ }^{130}$ Moreover, they are granted access to all relevant information and have the right to attend all police hearings. The role of lawyers in the police custody procedure was revaluated in 2011 in part on account of the European Court of Human Rights' decision in Brusco v France, ${ }^{131}$ which found that the French legal system of police custody was in breach of article 6 of the ECHR. This finding has motivated the French legislator to better protect fundamental rights in police custody procedures.

Interestingly, the legal guarantees provided by the legislation on police custody are not the same as those set up by the new legislation on the special detention of aliens. The rules that apply to police custody should have been considered minimum standards to be respected by any other special procedure that restricts an individual's freedoms. Sadly, this is not the case. For instance, the law of 31 December 2012 does not mention the right to remain silent. By contrast, this was the main point considered by the European Court of Human Rights in the Brusco case, in which the Court affirmed that 'as regards the privilege against selfincrimination or the right to remain silent, the Court reiterates that these are generally recognised international standards which lie at the heart of a fair procedure'. ${ }^{132}$

In sum, the newly adopted procedure of detention leads to the inadequate protection of illegal immigrants' fundamental rights. Consequently, we agree, by analogy, with Mary Bosworth's affirmation that 'detainees are often disadvantaged relative to prisoners'.133

\footnotetext{
${ }^{125}$ Article L611-1-1 Code on the Entry and Residence of Foreigners and the Right of Asylum.

${ }^{126} \mathrm{CNCDH}$, Advisory Opinion, above n 112, 9.

${ }^{127}$ On the role of charities and non-governmental organisations in detention centres, see Article R553-14 Code on the Entry and Residence of Foreigners and the Right of Asylum. CE, Ministère de l'Immigration $v$ Association Collectif Respect, no 328826, 16 November 2009. TA Paris, Gisti and others, no 0816512/3-3, 14 October 2008. O Brachet, 'Nous sommes désormais passés dans un système de marché' (Le Nouvel Observateur, 25 September 2008). Cimade (2007), Centres et locaux de retention administrative, Rapport 2007 (27 April 2009) <www.cimade.org> accessed 24 May 2014.

${ }^{128}$ Article L611-1-1 Code on the Entry and Residence of Foreigners and the Right of Asylum.

${ }^{129}$ Law 2011-392, 14 April 2011, OJ 8915 April 2011.

${ }^{130}$ Article 63-3-1 Code of Criminal Procedure.

${ }^{131}$ Brusco v France App no 1466/07 (ECtHR, 14 October 2010). See also Salduz v Turkey App no. 36391/02 (ECtHR, 27 November 2008).

${ }^{132}$ Brusco $v$ France, ibid 44.

${ }^{133}$ Bosworth, above n 57, 173.
} 
Mutatis mutandis, we note that in the French system, immigrants detained under these new special proceedings are at a disadvantage compared with ordinary criminal suspects placed in police custody.

It can thus be legitimately argued that aliens' rights were better protected under the police custody procedure before the First Civil Chamber of the Court of Cassation decisions. ${ }^{134}$ The Court of Cassation's decisions have indeed contributed to the transformation of detention into an ordinary tool for managing immigration by the French authorities, instead of the last-resort coercive measure that it is supposed to be in all EU Member States.

\section{Conclusion}

The decisions of the First Civil Chamber of the Court of Cassation ${ }^{135}$ have turned upside down the whole system of custody and detention of undocumented immigrants in France. As a result, legislative reform ${ }^{136}$ has not been able to satisfactorily balance individual rights and general public interest. Aliens' fundamental rights are definitely less well protected than those of persons kept in police custody, even though the former are not suspected of committing a criminal offence. Their only 'offence' is to find themselves in a situation of illegal stay.

The government's rather underhand way of justifying such a lack of protection of fundamental rights is to set the new procedure formally outside of the criminal domain. Nevertheless, there is no "water-tight division" ${ }^{137}$ separating the immigration control sphere from the field of criminal law in this legislation.

In this respect, reference ought to be made to article 78-2 of the Code of Criminal Procedure. This article provides prosecutors with the possibility of requiring identity controls on anyone suspected of committing criminal offences ranging from terrorism to robbery or drug trafficking. An alien suspected of committing one of these offences could be placed under the proposed procedure of identity verification, and although in this case placement in police custody would be lawful, the defence rights of the alien would be less well protected. According to the First Civil Chamber of the Court of Cassation, the placement in police custody of an alien is unlawful only if it is motivated by a decision taken on the sole ground of illegality of stay. If the alien is also suspected of committing one of the criminal offences enumerated by article 78-2 of the Code of Criminal Procedure, and if he or she is caught in the act, then placement in police custody is possible, lawful and probably desirable.

Following the adoption of the legislative reform, the 'effet utile' of Directive 2008/115 has been safeguarded, although the standard of protection of the fundamental rights of aliens has decreased. In other words, the efficiency of removal prescribed by the Directive has been accomplished, albeit with the parallel reduction in the protection of fundamental rights.

\footnotetext{
${ }^{134}$ Cass. 1re civ., 5 July 2012, above n 3.

135 ibid.

${ }^{136}$ Law 2012-1560, above n 28.

${ }^{137}$ In a very different context, expression used by the European Court of Human Rights: Airey v Ireland App no 6289/73 (ECtHR 9 October 1979) [26].
} 
The new procedure of detention for the verification of identity and legality of stay provides fewer guarantees of fundamental rights than the procedure of placement in police custody. Hence, by declaring the latter unlawful, the supposed step towards a less criminal treatment of undocumented immigrants in France has, in reality, resulted in a more restrictive and less protective procedure.

One step forward by the Court of Cassation has led to two steps sideways by the legislator. The government, wary of promises to stamp out illegal immigration made during the presidential campaign, has tried to keep the balance in the dance by performing impressive legal pirouettes. Although the trio of dancers may have avoided tumbling into a politically risky territory, their dancing shoes have trampled mercilessly on the rights of one of the weakest social groups in France. 